\title{
THE GEOTOURIST ATTRACTIVENESS OF LAGOWICA RIVER VALLEY (HOLY CROSS MOUNTAINS, POLAND) - A PROJECT OF A GEOTOURIST TRAIL
}

\author{
Malgorzata LUDWIKOWSKA-KĘDZIA* \\ Jan Kochanowski University, Institute of Geography and Environmental Sciences, \\ 7 Uniwersytecka Street, 25-435 Kielce, Poland, e-mail: malgorzata.ludwikowska@ujk.edu.pl \\ Malgorzata WIATRAK \\ Kielce University of Technology, Faculty of Civil Engineering and Architecture, \\ 7 Tysiąclecia Państwa Polskiego Avenue, 25-314 Kielce, Poland, e-mail: mwiatrak@tu.kielce.pl
}

\begin{abstract}
Citation: Ludwikowska-Kędzia, M., \& Wiatrak, M. (2020). THE GEOTOURIST ATTRACTIVENESS OF ŁAGOWICA RIVER VALLEY (HOLY CROSS MOUNTAINS, POLAND) - A PROJECT OF A GEOTOURIST TRAIL. GeoJournal of Tourism and Geosites, $32(4), 1337-1346$. https://doi.org/10.30892/gtg.32422-578
\end{abstract}

\begin{abstract}
Geotourist evaluation of thirteen small geological, geomorphological and mining heritage objects was carried out in a small valley of the Upper Łagowica River and in its surroundings (Holy Cross Mountains, Poland). The point grading method was used, which is functional in the case of evaluation of small geotourist objects. It was shown that the analysed objects are characterized by high and medium geotourist attractiveness. When analysed together, they strengthen their own individual values. They are suited to mark out geotourist trails (geotrail), and additionally become a source of information about spatial changes of geodiversity. They also determine the uniquenes s of this type of small river valleys of the Holy Cross Mountains on a regional and supra-regional scale. The evaluation of these objects and the proposal of a geotourist trail in the Upper Lagowica River valley may contribute to the activation of local communities and government authorities in the promotion of geoeducation and geotourism, draw their attention to the need for preservation and protection of the geodiversity of small valleys of the Holy Cross Mountains, and, what is especially important, may give information about the investment attractiveness of the area.
\end{abstract}

Key words: geotourist attractiveness, fluvial valley, geotrail, Holy Cross Mts., Poland

\section{INTRODUCTION}

Holy Cross Mountains (south part of Poland) (Figure 1a) are characterized by a high degree of geodiversity (Wróblewski, 2000; Urban and Gągol, 2008), understood primarily as the diversity of the Earth's heritage (geoheritage), i.e. geological heritage (Najwer and Zwoliński, 2014) and geomorphological heritage (geomorphodiversity according to Zwoliński, 2004; Panizza, 2009). Paleozoic massif of the Holy Cross Mountains has diverse lithology - coexisting clastic and carbonate rocks and fold-block structure (e.g. Kotański, 1959; Stupnicka and Stempień-Sałek, 2016). The geological structure of the Holy Cross Mountains determines the features of their relief, unique in Poland, i.e. parallel pattern of ridges separated by depressions (Wróblewski, 1977; Urban, 2014) of tectonic and erosion-denudation origin (Kowalski, 2002; Ludwikowska-Kędzia, 2018). These morphostructural conditions determined the development of concentric river network, with picturesque gorge sections. It is also the area where various mineral resources occur (e.g. iron and lead ore), the tradition of mining and processing of which dates back to ancient times (e.g. Kowalczewski, 1971; Orzechowski, 2007).

These facts allow us to regard the Holy Cross Mountains as an attractive geotourist area, where numerous geological and geomorphological objects, both natural and anthropogenic, appropriately prepared and adapted (cf. Prosser et al., 2006), can be a local and/or a regional geotourist product (e.g. Kaczmarek et al., 2010; Dryglas and Miśkiewicz, 2014).

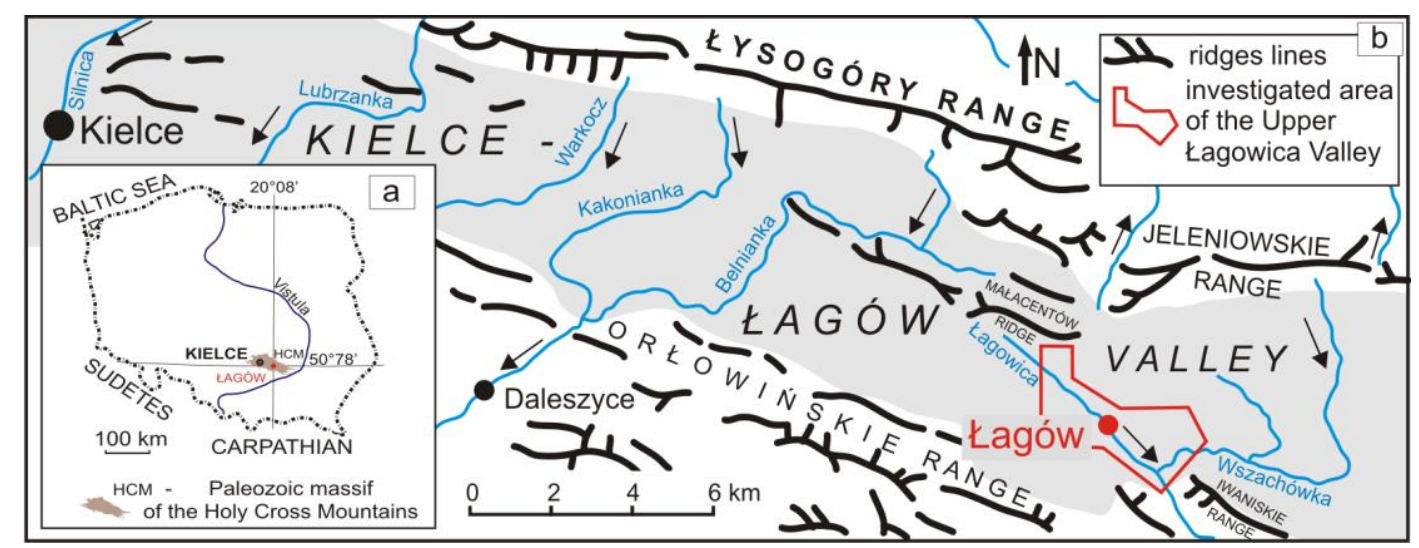

Figure 1. Location of the study area in Poland (a) and in relation to relief features of the Kielce-Lagów Valley (after Wróblewski 1977) (b)

Geological and geomorphological objects, successfully adapted for a wide range of tourists in the Holy Cross Mountains and often covered by legal protection, are closed quarries, for example Kadzielnia, Śluchowice, Wietrznia, which are located within the city limits of Kielce (e.g. Nita, 2012; Nita and Myga-Piątek, 2014) or karst caves, e.g. Raj Cave (Rubinowski, 1974). Such objects and methods of their

\footnotetext{
${ }^{*}$ Corresponding author
} 
adaptation are the subject of special attention in the region, and are promoted, among others, as part of the planned activities and initiatives for the creation of geoparks, thus the development of geotourism in the Świętokrzyskie region (Strzyż and Wójtowicz, 2011).

However, it is worth paying attention to the geotourism potential of equally valuable, natural geological and geomorphological objects located in small river valleys of the Holy Cross Mountains (Ludwikowska-Kędzia and Wiatrak, 2012). The lengths of these rivers range from 30 to $36 \mathrm{~km}$, and the areas of their catchments - from 190 to $280 \mathrm{~km}^{2}$. These objects can be examined individually, as geosites and geodiversity sites (Alexandrowicz and Alexandrowicz, 2002; Dowling, 2011; Brilha, 2016) and/or geomorphosites (Panizza, 2001; Reynard and Panizza, 2005; Mucivuna et al., 2019). It was assumed that, due to their small size, concentration in the valleys, and location in close proximity to each other, these objects, when analysed together, have a chance to strengthen their own indi vidual values and additionally become a source of information about spatial changes of geodiversity (sensu ANHC 2002; Najwer and Zwoliński, 2014). Therefore, they need geotourist evaluation, the more so because the evaluation of geotourist attractiveness of the objects located in small river valleys of the Holy Cross Mountains is sporadic (Ludwikowska-Kędzia and Wiatrak, 2012). An additional argument for the need for evaluation is poor knowledge and lack of awareness among local communities about the value of the aforementioned geological and geomorphological objects in river valleys. This fact, as well as overexploitation of mineral resources, construction of hydrotechnical facilities (e.g. sewage treatment plants in zones of picturesque river gorges or ravines), and pollution with various types of waste, hinder an integrated and holistic approach in the management policy of the inanimate nature resources and mining heritage of the Holy Cross Mountains (e.g. Kowalczyk and Szrek, 2011). It seems that this problem also applies to other areas of Poland and the world, where geotourist evaluation is carried out mainly in the valleys of greater rivers (e.g. Kot, 2006; Hełdak, 2016).

\section{MATERIAL AND METHODS}

The aim of the study is to evaluate geotourist attractiveness of thirteen small geological, geomorphological and mining heritage objects, which are located in the Upper Łagowica River valley belonging to the category of small river valleys of the Holy Cross Mountains (Figure 1, 2; Table 1), and to suggest their transformation into geoproducts in the category of trail (according to Dryglas and Miśkiewicz, 2014; Jawecki and Tarka, 2017). The Upper Łagowica River valley is located in the southern part of the Holy Cross Mountains, in the eastern part of the Kielce-Łagów Valley (Wróblewski, 1977) (Figure 1b). The source of the Lagowica River is located at the foot of the southern slopes of the Małacentów Ridge (330 m a.s.1.).

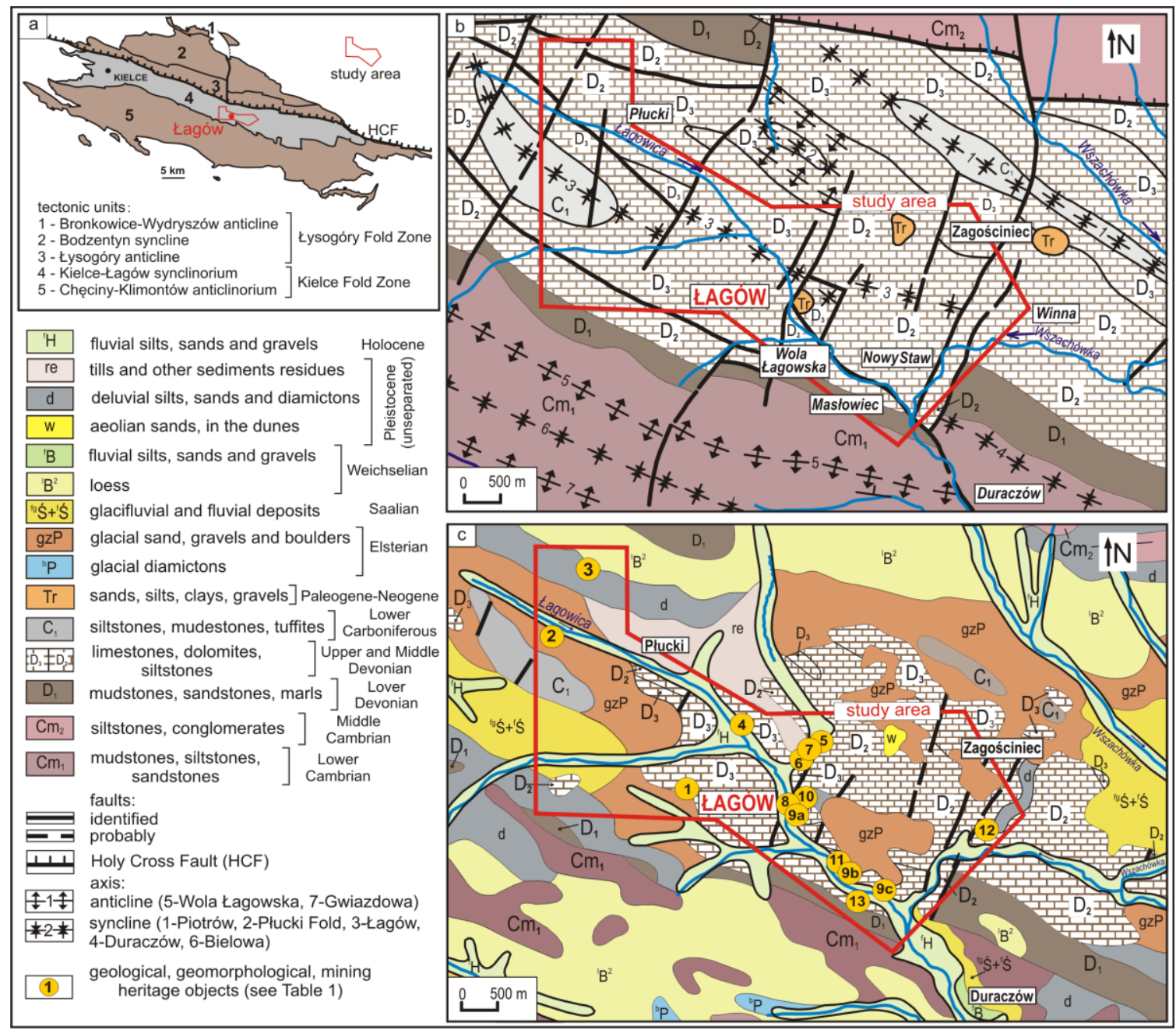

Figure 2. Location of the study area in relation to tectonic units of the Paleozoic massif of the Holy Cross Mountains (based on Znosko 1962; Konon 2008) (a), geological map of study area: without the Quaternary deposits

(based on Romanek and Złonkiewicz, 1992) (b) and with the surface sediments (based on Janiec et al., 1992) (c)

Administratively, the Upper Łagowica River valley is located in the Świętokrzyskie Province, Łagów commune. The Łagów commune has a good communication location, numerous bicycle and tourist routes. The protected landscape areas, the natural la ndscape complexes, the Natura 2000 area and nature monuments occur in the Upper Lagowica River valley and its surroundings (Ludwikowska- 
Kędzia and Wiatrak, 2012). The Upper Lagowica River valley and its surroundings have been selected for the research due to the following features, which particularly predispose this area to the development of geotourism: (1) unique geological structure (fold-block structure; the Middle and Upper Devonian dolomites and limestones adjacent to the Lower Cambrian, Lower Devonian and Lower Carboniferous clastic rocks - mainly sandstones and siltstones; polygenic cover of the Quaternary deposits) (Figure 2 a-c), (2) relief (with the preserved features of karst landscape, i.e. sinkholes, ponors, karst ribs, karst springs and caves) (e.g. Fijałkowska and Fijałkowski, 1971; Urban and Rzonca, 2009; Urban et al., 2019) and (3) mining history (i.e. the period of Roman influence with the iron mining and metallurgy, and late Middle Ages (14th - 16th century) with lead and iron mining, pottery and glassworks) (e.g. Kowalczewski, 1971; Fijałkowska and Fijałkowski, 1971; Hadamik, 2004; Kubicki and Saletra, 2013).

Table 1. Main information about small geological, geomorphological and mining heritage objects in the Upper Łagowica River valley

\begin{tabular}{|c|c|c|}
\hline $\begin{array}{c}\text { Object } \\
\text { No. }\end{array}$ & Information about the objects & $\begin{array}{l}\text { Example references } \\
\text { (and references ibid) }\end{array}$ \\
\hline $1-2$ & $\begin{array}{l}\text { Nawrocki shaft in Lagów (depth of } 23 \mathrm{~m}, 3 \text { levels of galleries) and Traces of galena mining in Plucki (e.g. } \\
\text { bowl-shaped hollows) - lead mining post-exploitation areas }\end{array}$ & $\begin{array}{l}\text { Kowalczewski, 1971; Rubinowski, } \\
\text { 1971; Fijałkowski, } 1972\end{array}$ \\
\hline 3 & $\begin{array}{l}\text { Polygenic depressions in the Malacentów Ridge - an example of reproduced karst forms controlled by tectonic } \\
\text { and lithological boundaries of the Paleozoic bedrock (Figure 3a); their development was also affected by } \\
\text { suffusion and surface wash processes and deflation of material from the Quaternary covers }\end{array}$ & $\begin{array}{l}\text { Ludwikowska-Kędzia } \\
\text { et al., } 2019\end{array}$ \\
\hline 4 & $\begin{array}{l}\text { Exposure of the Frasnian-Famennian (F-F) limestones in Plucki - the geological profile contains a layer of black } \\
\text { limestone, until recently considered to be a record of the worldwide anaerobic episode at the end of the Frasnian and } \\
\text { corresponding to the Upper Kellwasser Horizon (Figure 3b); it contains invertebrate fauna: e.g. Bivalia (Figure 3b-1), } \\
\text { Nautiloidea (Figure 3b-2), Goniatitida, Brachiopoda, and Chordata (e.g. Placodermi, Tetrapodomorpha) }\end{array}$ & Szrek and Salwa, 2020 \\
\hline 5 & $\begin{array}{l}\text { Dule karst gully in Lagów - the origin of this form can be related to the gradual collapse of roof of cave } \\
\text { corridors or the joining of several sinkholes; one of the most distinct forms in the landscape of the Lagów- } \\
\text { Klimontów karst subregion of the Holy Cross Mountains }\end{array}$ & $\begin{array}{c}\text { Kotański, 1959; } \\
\text { Walczowski, 1962; }\end{array}$ \\
\hline 6 & $\begin{array}{l}\text { Exposure of the Famennian limestones - the geological profile contains unique and species-rich cephalopod } \\
\text { fauna with new species of Nautiloidea, Goniatitida and Clymeniida; for some of these cephalopods, it is the only } \\
\text { place of their occurrence known in the Holy Cross Mountains }\end{array}$ & $\begin{array}{l}\text { Wróblewski, 2000; } \\
\text { Dzik, } 2006\end{array}$ \\
\hline 7 & $\begin{array}{l}\text { Zbójecka Cave in the Dule gully - the form of karst-collapse origin, which was formed in Neogene (Figure } \\
3 \mathrm{c}, \mathrm{d}, \mathrm{e}) \text {; typical carbonate dripstone formations and unique rock formations; fauna of troglobionts, troglophiles, } \\
\text { trogloxenes and several species of bats live in the cave; the fragments of medieval pottery from the 13th and 14th } \\
\text { centuries have been found there }\end{array}$ & $\begin{array}{l}\text { Kotański, 1959; Urban, 1996; } \\
\text { Urban and Rzonca, 2009; } \\
\quad \text { Hadamik, } 2004\end{array}$ \\
\hline 8 & $\begin{array}{l}\text { Ravine of the Lagowica River between Lagów and Nowy Staw - the form developed within a tectonic zone } \\
\text { and a contact zone of limestones and dolomites with sandstones; it was formed as a result of the erosion activity } \\
\text { of constantly flowing surface water or the emerging of underground river, e.g. due to the collapse of cave roof }\end{array}$ & $\begin{array}{l}\text { Ludwikowska-Kędzia } \\
\text { and Wiatrak, 2012; }\end{array}$ \\
\hline $9 a-c$ & $\begin{array}{l}\text { Exposure of the Devonian carbonate series between Lagów and Nowy Staw - the only place in the Holy } \\
\text { Cross Mountains with the natural exposure of a complete profile of the Devonian carbonate series, from Eifelian } \\
\text { to Famennian (Figure 3f); rocks represent a carbonate platform formed in shallow water and contain a variety of } \\
\text { benthos fauna, Stromatopora (Figure 3g), Amphipora (Figure 3h, i-1), Anthozoa (Figure 3h, i-2), Brachiopoda } \\
\text { and Crinoidea }\end{array}$ & $\begin{array}{c}\text { Czermiński, 1960; } \\
\text { Grabowski et al., } 2006\end{array}$ \\
\hline 10 & $\begin{array}{l}\text { Lisia Dziura Cave in the slope of the Lagowica River ravine - a form conditioned by the occurrence of two } \\
\text { faults, joint fissures, and layer jointing in the Givetian limestone (Figure } 3 \mathrm{j} \text { ); the cave developed probably in the } \\
\text { Cenozoic (Pleistocene) karst period }\end{array}$ & $\begin{array}{l}\text { Czermiński, 1960; } \\
\text { Urban, 1996; } \\
\text { Urban and Rzonca, } 2009\end{array}$ \\
\hline 11 & $\begin{array}{l}\text { Karst spring in Masłowiec - the discharge of this spring }(10-501 / \mathrm{s}) \text { is the highest among the other karst springs } \\
\text { feeding the Lagowica River; its water temperature of } 9^{\circ} \mathrm{C} \text { is constant }\end{array}$ & $\begin{array}{l}\text { Walczowski, 1968; } \\
\text { Wróblewski, } 2000\end{array}$ \\
\hline 12 & $\begin{array}{l}\text { Mining area near Winna and Komorniki - geological profile shows the arrangement of the Middle Devonian } \\
\text { dolomite layers (Figure 3k), fault surfaces with mineralized slickensides, veins and nests (mainly of calcite and } \\
\text { dolomite) and sinkholes (filled with the Miocene kaolinite-illite clays containing lenses of sand and quartz } \\
\text { gravel) (Figure 31,m); near Winna there is a heap from the 1930s - the remnant of a closed pyrite mine }\end{array}$ & $\begin{array}{l}\text { Uberna, 1962a,b; Fijałkowska } \\
\text { and Fijałkowski, 1971; } \\
\text { Ludwikowska-Kędzia, 2013; } \\
\text { Kasza and Król, } 2019\end{array}$ \\
\hline 13 & $\begin{array}{l}\text { Profile of Quaternary deposits in Maslowiec - geological profile situated in a closed sandpit is a record of the } \\
\text { Plenivistulian stage of aggradation, in which fluvial and slope (mainly slopewash, rarely solifluction) processes } \\
\text { cooperated, and which took place in the narrow bottom of the Lagowica River valley (Figure 3n) }\end{array}$ & $\begin{array}{c}\text { Ludwikowska-Kędzia et al., } \\
\text { 2006; Ludwikowska-Kędzia } \\
\text { and Wiatrak, } 2012\end{array}$ \\
\hline
\end{tabular}

The usefulness and importance of geotourist evaluation conducted in small river valleys of the Holy Cross Mountains has been already assumed at the initial stage of the promotion of geoeducation idea in the Lagów region (since 2010) (among others LudwikowskaKędzia and Wiatrak, 2010). The research carried out at that time showed that the studied geotourist objects were characterized by high and medium educational value and geotourist attractiveness. Dissemination of the research results among the local community and the authorities of the city and commune of Łagów took place in the form of lectures and all-Poland conferences as well as educational meetings in Łagów. Based on the assessment of the importance and effectiveness of this preliminary evaluation, we decided to continue the research and to expand the geoeducational - geotourist offer with other objects, and thereby to modify the geotourist trail (cf. Ludwikowska-Kędzia and Wiatrak, 2012). This decision was also dictated by the need to protect the geodiversity of this unique area in the Holy Cross Mountains, taking into account the constantly increasing exploitation of dolomites and limestones in the Lagów region.

The evaluation of geotourist attractiveness of small geological, geomorphological and mining heritage objects in the Łagowica River valley was carried out again using the method published by Dmytrowski and Kicińska (2011) (Table 2). They proposed the evaluation of a given object according to 20 criteria constituting the substantive value (I), location value (II), cultural value (III) as well as availability and accessibility of information about a given object (IV), which together allow us to evaluate its educational (didactic) value (EV).

In addition, it is possible to assess the level of geotourist infrastructure de velopment, that is, to determine the infrastructure value (V) according to Dmytrowski and Kicińska (2011). The educational value (EV) and the infrastructure value (V) determine the geotou rist attractiveness (GA) of a given area.

This method is intended for evaluation of small geotourist objects. It takes into account the main groups of criteria for geotourist evaluation of geological heritage objects - geosites (cf. Brilha 2016) and geomorphosites (e.g. Mucivuna et al., 2019), which have been proposed in other methodological solutions (e.g. Alexandrowicz et al., 1992; Reynard et al., 2007; Bruschi et al., 2011; Fassoulas et al., 2012; Kubalíková, 2013; Brilha, 2016; Mucivuna et al., 2019), and additionally it draws attention to the aspect of development, management and aesthetic (visual) values of the studied objects. 

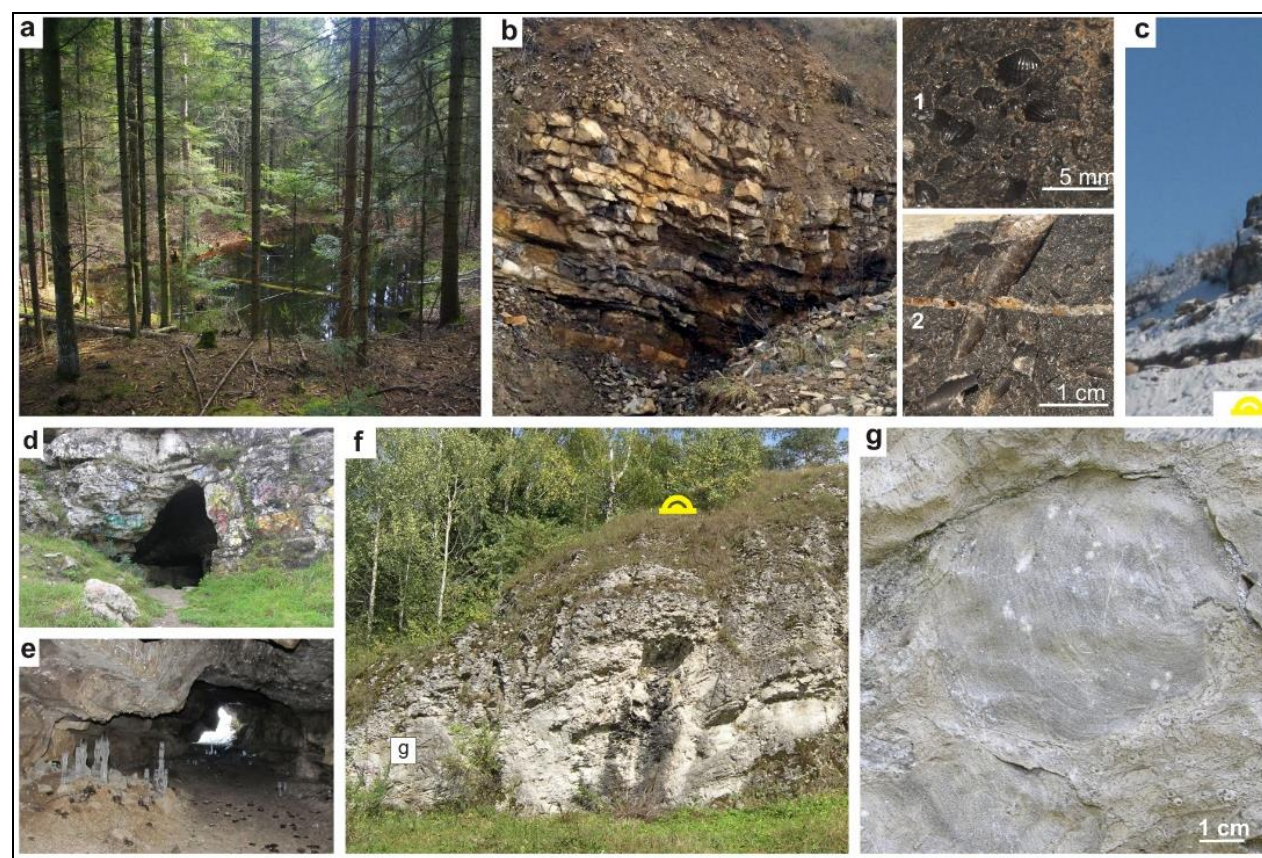

entrance hole of the cave

h
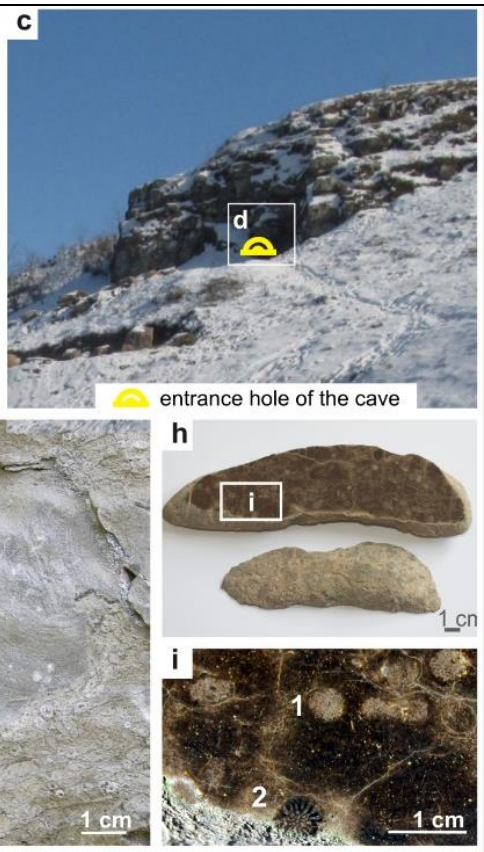
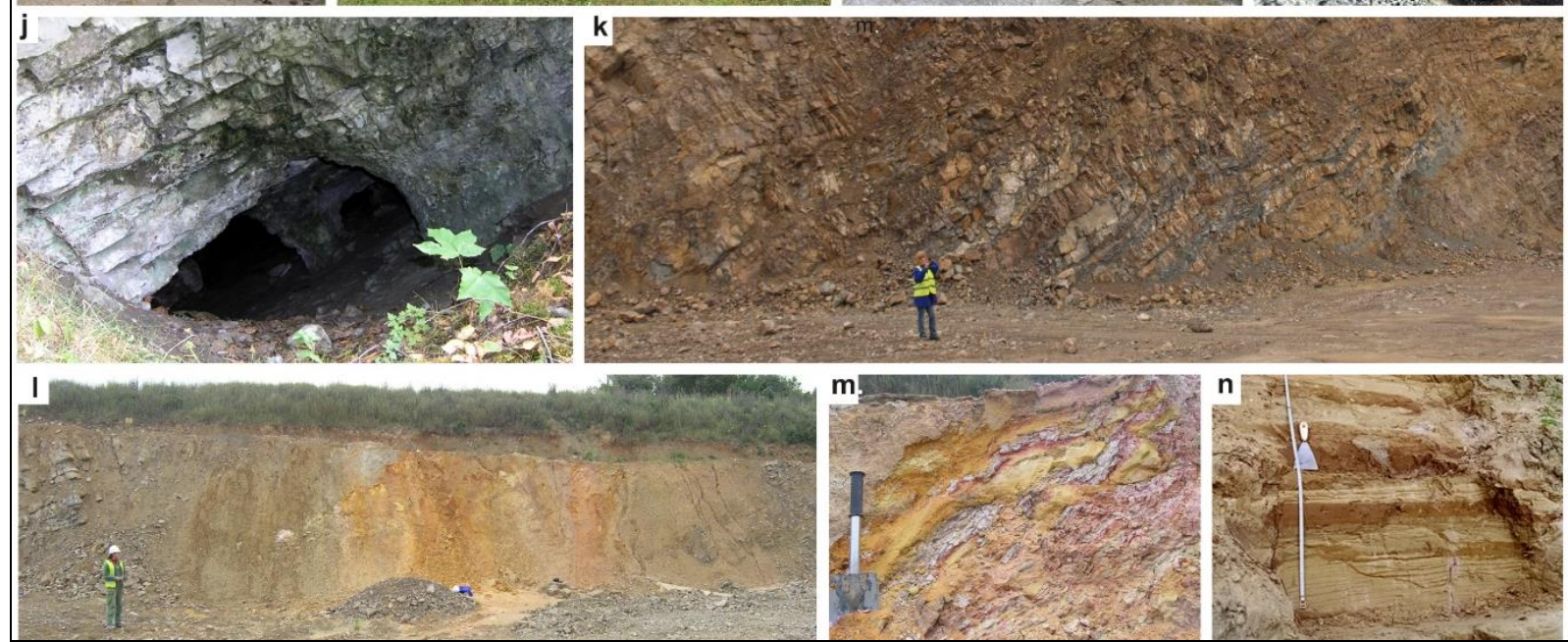

Figure 3. Geological and geomorphological objects in the Upper Łagowica River valley: a - closed depression forms on the slope of the Małacentów Ridge, b - exposure of the Frasnian-Famennian (F-F) limestones in Płucki with fossil fauna: Bivalia (1), Nautiloidea (2), c - slope of the Dulle gully with the Zbójecka Cave; d - entrance hole of the Zbójecka Cave, e - ice stalagmites in Zbójecka Cave corridor, f - exposure of the Givetian limestones in the ravine of the Lagowica River Valley with the location of the Lisia Dziura Cave entrance, $\mathrm{g}$ - the massive colony of Stromatopora in the Givetian limestones, $\mathrm{h}$ - a cut of limestone and weathered limestone with fauna; i - cross-sections through the skeletal elements of Amphipora (1) and Anthozoa (2) of the Devonian carbonate series, $\mathrm{j}$ - the Lisia Dziura Cave entrance, $\mathrm{k}$ - layers of dolomites in the Winna Quarry, 1 - sinkhole in the Winna Quarry, $\mathrm{m}$ - Paleogene-Neogene filling with clays containing lenses of sand and quartz gravel, $\mathrm{n}$ - Quaternary deposits series in the Łagowica River valley near Masłowiec. Photos by Małgorzata Ludwikowska-Kędzia (a, b, d-g, j, 1-n), Jan Urban (c), Małgorzata Wiatrak (b1-2, h, i, k)

Table 2. Evaluation and score range of individual geotourist values after Dmytrowski and Kicińska (2011)

\begin{tabular}{|c|c|c|c|c|}
\hline \multirow{2}{*}{ Values } & \multirow{2}{*}{ Elements of evaluation } & \multicolumn{3}{|c|}{ Evaluation and score range } \\
\hline & & High & Medium & Low \\
\hline \multirow[b]{2}{*}{$\begin{array}{l}\text { I } \\
\text { substantive }\end{array}$} & \multirow{2}{*}{$\begin{array}{l}\text { Score range: } 1-3 \text { points } \\
\text { a) significance of a given object in the geological structure and geomorphology of the region, b) occurrence of } \\
\text { unique geological structures, c) occurrence of rocks with unique petrographic-mineralogical characteristics, d) } \\
\text { readability of geological structure and processes, e) state of a given object, f) size of a given object, g) } \\
\text { aesthetic values, h) concentration of objects of the same type in a given region. }\end{array}$} & \multicolumn{3}{|c|}{$\mathrm{I}=\mathrm{Ia}+\ldots \mathrm{Ih}$} \\
\hline & & $>17$ & $17-10$ & $<10$ \\
\hline \multirow{2}{*}{$\begin{array}{c}\text { II } \\
\text { location }\end{array}$} & \multirow{2}{*}{$\begin{array}{l}\text { Score range: } 1-3 \text { points a) location relative to transport routes, b) location relative to tourist trails, c) location } \\
\text { relative to tourist centres; d) the degree of difficulty of exploring. }\end{array}$} & \multicolumn{3}{|c|}{$\mathrm{II}=\mathrm{IIa}+\ldots \mathrm{IId}$} \\
\hline & & $>8$ & $8-5$ & $<5$ \\
\hline \multirow{2}{*}{$\begin{array}{c}\text { III } \\
\text { cultural }\end{array}$} & \multirow{2}{*}{$\begin{array}{l}\text { Score range: 1- yes; 0-noconnection of a given object with: } \\
\text { a) the history of a given region, b) the history of mining exploitation, c) regional legends. }\end{array}$} & \multicolumn{3}{|c|}{$\mathrm{III}=\mathrm{IIIa}+\ldots \mathrm{IIIc}$} \\
\hline & & 3 & $<3$ & $<2$ \\
\hline \multirow{2}{*}{$\begin{array}{l}\text { IV } \\
\text { information }\end{array}$} & \multirow{2}{*}{$\begin{array}{l}\text { Score range: 1-3 points a) availability and accessibility of information about a given object in non-specialist } \\
\text { and specialist literature and on the Internet. }\end{array}$} & \multicolumn{3}{|c|}{ IV=IVa } \\
\hline & & 3 & $<3$ & $<2$ \\
\hline & & \multicolumn{3}{|c|}{$\mathrm{EV}=\mathrm{I}+\mathrm{II}+\mathrm{III}+\mathrm{IV}$} \\
\hline & educational value & $>31$ & $31-24$ & $<19$ \\
\hline \multirow{2}{*}{$\begin{array}{c}\mathbf{V} \\
\text { geotourist } \\
\text { development }\end{array}$} & Score range: $1-3$ points & \multicolumn{3}{|c|}{$\mathbf{V}=\mathbf{V a}+\ldots \mathbf{V d}$} \\
\hline & $\begin{array}{l}\text { a) administration and management of a given object, b) information board next to a given object, } \\
\text { c) geotourist trail, d) accompanying development. }\end{array}$ & $>8$ & $8-5$ & 5 \\
\hline & GA & \multicolumn{3}{|c|}{$\mathbf{G A}=\mathbf{E V}+\mathbf{V}$} \\
\hline & geotourist attractiveness & $>39$ & $39-24$ & $<24$ \\
\hline
\end{tabular}




\section{RESULTS AND DISCUSSION}

Evaluation of geotourist attractiveness of the objects in the Upper Lagowica River Valley

The results of geotourist evaluation of thirteen objects occurring in the Upper Łagowica River valley, i.e. partial evaluation (separately each value) and final evaluation (educational value, geotourist attractiveness) of each object (Table 3), lead us to the following conclusions:

Table 3. Geotourist evaluation of the objects in the Upper Lagowica River valley (after Ludwikowska-Kędzia and Wiatrak, 2012; partially modified)

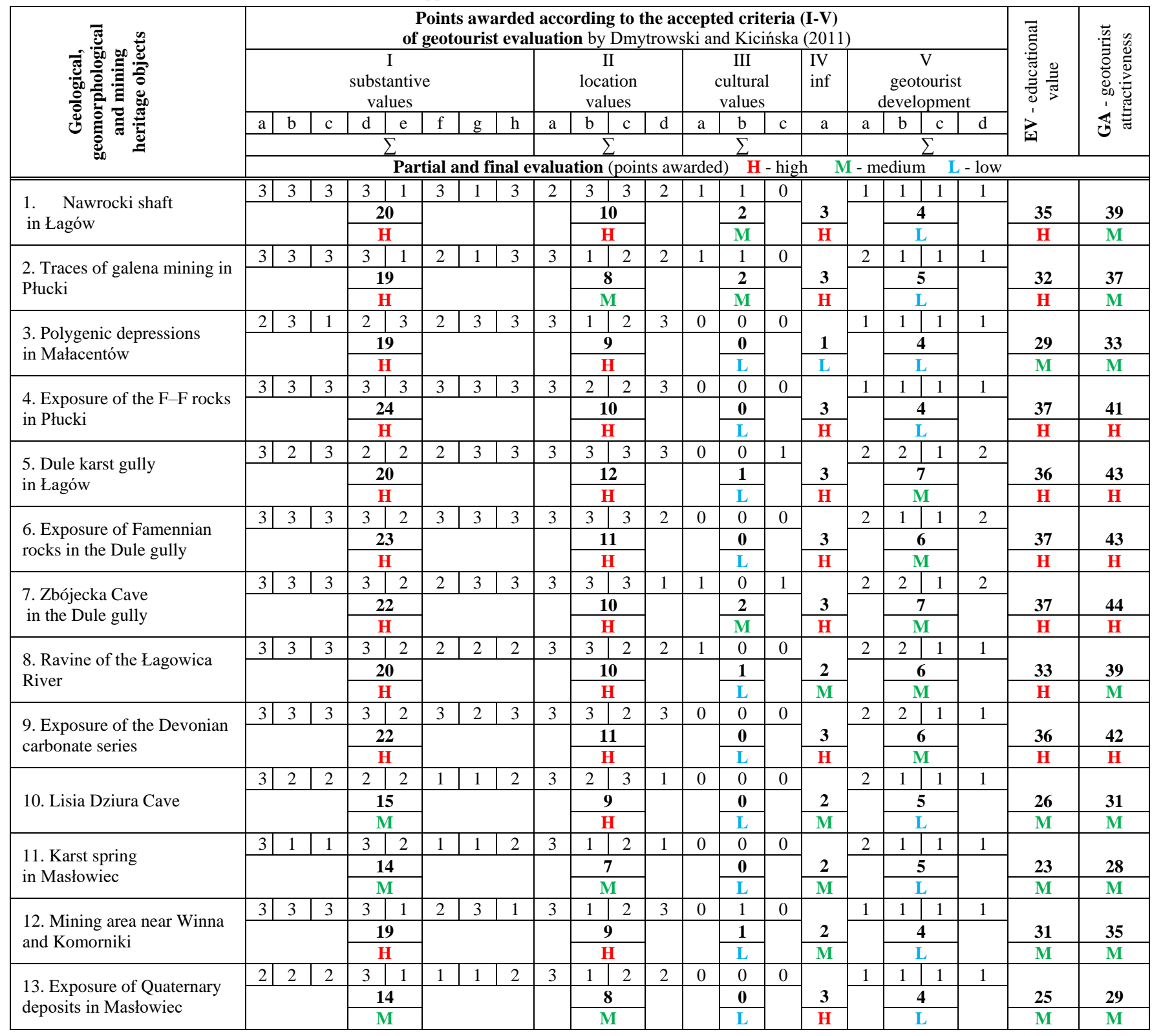

(a) four objects (4,6,7 and 9) have the highest substantive value (I) (22-24 points out of 24 possible). They can be considered as geosites (cf. Brilha, 2016). The second place (19-21 points) is taken by six geomorphological and mining heritage objects (1-3,5,8 and 12). The substantive value of the remaining objects (three) ranges from 14 to 15 points (objects 10,11,13), i.e. it is average.

The common feature of most objects (eleven out of thirteen evaluated) is the maximum evaluation according to the criterion of significance of a given object in the geological structure and geomorphology of the region (objects 1, 2, 4-12), and according to the criterion of the state of a given object (objects 1, 2, 5-13). This indicates high rank of these objects. It is necessary to look after them so that their substantive value remains high.

(b) ten objects has a high location value (II), within the range of 9-12 points (objects 1, 3-10, 12), which results, among others, from their location near the road (up to $1 \mathrm{~km}$ ) with a place to stop for cars, in the city of Lagów (a tourist centre in the eastern part of the Holy Cross Mountains) or on its outskirts. Only three objects have an average location value (7-8 points; objects 2, 11 and 13).

(c) only three objects have average cultural value (III), i.e. these connected with former galena mining (objects 1-2) and settlement (object 7). The cultural value of other objects is low.

d) only one object (object 3) has low information value (IV), while for the others this value is high (eight objects) or average (four objects). This is due to the fact that the investigations and making accessible the object 3 are in the early phase, while the other objects are known from the literature presenting the history of over two hundred years of geological and geomorphological research conducted in the Holy Cross Mountains region.

(e) eight analysed objects (objects $1,2,4-9)$ have high educational value (EV $=32-37$ points) and five have average value $(\mathrm{EV}=23-31$ points). These results indicate that the educational potential of these geotourist objects is high and fully justifies the need for their promotion. 
(f) infrastructure value (geotourist infrastructure) of eight analysed geotourist objects is low (4-5 points; objects 1-4, 10-13), in fact it does not exist. The other objects have average value (6-7 points, objects 5-9) because they meet three criteria at the same time: (1) clear legal status resulting from the fact that they are protected by law as nature monuments, natural-landscape complexes or parts of area of protected landscape, (2) existence of didactic boards though the content of them needs to be revised, and (3) planning and implementation of investment works by the local authorities of the city and commune of Łagów in the last five years.

$(\mathrm{g})$ in the case of geotourist objects in the Upper Lagowica River valley, five objects $(4-7,9)$ are characterized by high (40-44 points) geotourist attractiveness (GA), and the remaining eight (objects 1-3, 8,10-13) have average attractiveness (28-39 points).

(h) none of the objects has low educational value $(\mathrm{EV})$ and low geotourist attractiveness $(\mathrm{GA})$. The lowest number of points $(\mathrm{EV}=23-26$ points, and $\mathrm{GA}=28-31$ points) were given to three objects $(10,11,13)$.

The number of points in the category of educational value (EV) of the analysed objects is so high that poor or non-existent geotourist infrastructure $(\mathrm{V})$ does not significantly affect the evaluation of their geotourist attractiveness (GA). Therefore, it is worth considering the importance of the infrastructure value (geotourist infrastructure) of an object for the evaluation of its geotourist attractiveness. Certainly, each object should be evaluated in terms of all values that constitute its geotourist attractivene ss. If we evaluate the geotourist objects that already exist and have geotourist infrastructure, then we evaluate the real geotourist attractiveness, and in fact this evaluation leads to the creation of their ranking list, and can be used to determine the directions of their modernization etc.

In the case of preliminary evaluation of geotourist objects with poor or non-existent geotourist infrastructure we can evaluate their potential geotourist attractiveness. In such a situation, the evaluation of the educational value (EV), i.e. the educational potential of an object, is of particular importance. The analysis of this value, together with the infrastructure value, will allow us not on ly to evaluate the potential geotourist attractiveness of the analysed objects, but also to select those objects, for which the potential geotourist attractiveness will turn into the real geotourist attractiveness after building geotourist infrastructure. In the case of the objects in the Upper Łagowica River valley, which have high educational value (e.g. the Dule gully, the Zbójecka Cave, the Lagowica River ravine, the exposure of carbonate series in its slope between Lagów and Nowy Staw), already a low number of points in the category of infrastructure value makes them attractive for geotourists. This fact suggests that when geotourist infrastructure will be complete, these objects certainly will obtain the status of the actual geotourist attraction of the area. On the other hand, in the case of objects with lower educa tional value (e.g. the karst spring and exposure of Quaternary deposits in Masłowiec, Lisia Dziura Cave) only a high number of points in the cat egory of infrastructure value would make them objects with high geotourist attractiveness. These suggestions are confirmed by the comparison of the research results obtained for the objects 1 and 2 in the years 2010-2011 and recently (cf. Ludwikowska-Kędzia and Wiatrak, 2012). The high geotourist attractiveness of these objects has decreased and nowadays it is average.

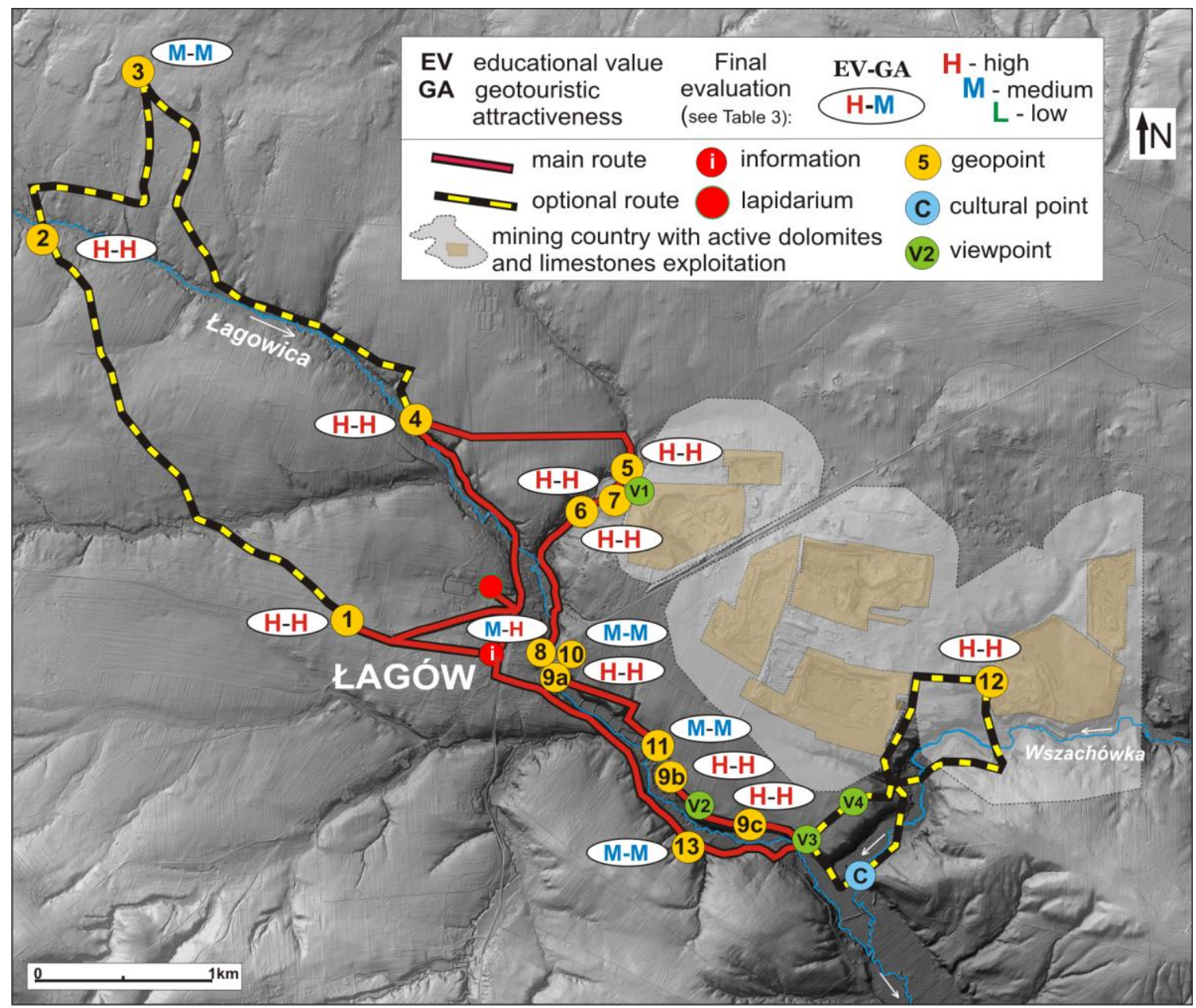

Figure 4. The project of geotourist trail “Upper Łagowica River Valley” (Ludwikowska-Kędzia and Wiatrak, 2012; partially modified)

It is interesting to notice that in the proximity of the Upper Lagowica River valley there are not only the objects that threaten its attractiveness and existence, but also the areas very promising as for extending the geotourist offer of the region. These are vast areas of exploitation of the Devonian deposits: limestone ( 5 mining areas), dolomite ( 2 mining areas), dolomite and limestone (1 mining area) 
(Szuflicki et al., 2020). The quarries irreversibly change the natural landscape features of these areas and the neighbouring, legally protected areas (Kowalczyk and Szrek, 2011). However, the post-exploitation areas (whole quarries or their fragments) do not have to be perceived as "wounds in the landscape" (Chwastek and Janusz, 1991). The mining managers as well as the local city and commune authorities should only change the formalistic way of thinking, already at the planning stage of liquidation of mining works and required reclamation of excavations and lands after mining activities. This stage is the right moment to see the chance of enriching the geotourist attractiveness of the area with new fascinating places, which illustrate on a large scale the effects of geological processes, and are located in the quarries of the Devonian limestone and dolomite near Łagów that will be closed in the future.

Many of these objects, appropriately adapted, can become extremely valuable geotourist, recreational (walking routes, bicycle paths, amphitheatres) or sports (climbing walls, football pitches) objects (cf. Nita, 2012). The results of geotourist evaluation clearly indicate very high geoeducational potential of the analysed small geotourist objects in the Upper Lagowica River valley, and thus confirm the idea of further promotion of geotourist development of the Lagów commune area, among other things by making the offered geoproduct more attractive, i.e. extending the proposed geotourist trail (cf. Ludwikowska-Kędzia and Wiatrak, 2012).

\section{Proposal of a geotourist trail in the Upper Lagowica River Valley}

Geotourist trail is a special kind of the route along which there are geotourist attractions, which are the main tourist cognitive motif (Kicińska-Świderska and Słomka, 2004) (Figure 4). The proposed geotourist trail in the Upper Łagowica River valley (Ludwikowska-Kędzia and Wiatrak, 2012) includes nineteen points. Thirteen of them are geological, geomorphological and mining geoheritage objects. Besides the above-mentioned objects, it was proposed to include: (1) information point (i), (2) cultural point on the Zamczysko Hill (C) with the remains of a medieval stronghold, which functioned from the end of the 11th century to the 13th century (Hadamik, 2004), and (3) four viewpoints on the rock platform with the Zbójecka Cave entrance (V1), in the highest part of the slope of the Lagowica River ravine (V2), on the slope of the Lagowica River ravine, near the mouth of the Wszachówka River (V3), and on the road to Nowy Staw (V4) (Figure 4). These viewpoints are important for highlighting the variability of relief of the analysed area, its natural aesthetic values (points V1, V3) and transformation of the natural landscape as a result of mining activities (points V1, V2, V4).

The proposed geotrail begins at the information point on the market square of Łagów, which received town privileges in $14^{\text {th }}$ century (Hadamik 2004). In this information point the history of mining and settlement in Łagów and the surrounding area could be presented as well as the general issues concerning the location, geological structure and relief of the Upper Lagowica River valley. Before setting off on the route, it will be worth stopping in the lapidarium, which is planned to be open by the city and commune authorities in the coming years (Figure 4). Starting from point 1, the trail runs successively through the evaluated objects. However, the objects 2 and 3 (in Płucki and on the Małacentów Ridge), due to their location outside the main course of the proposed geotrail, can be treated as alternative to the object 4 (Figure 4). Similarly, the objects $C$ and 12 (the Zamczysko Hill near Nowy Staw and the mining area near Winna and Komorniki) are alternative to the object 13 (the profile of Quaternary deposits in Masłowiec).

The proposed geoutourist trail in the Upper Łagowica River valley can be classified using the criteria published by Kicińska-Świderska and Słomka (2004):

(a) thematic criterion - specialist, geological and geomorphological trail, aimed at understanding the specificity of depositional conditions in the environments of shallow Devonian sea over the carbonate platform and deeper intrashelf basin, the conditions of development and features of karst relief (forms of surface and underground karst as well as reproduced karst), the Quaternary stage of the valley development, and the history of lead ore mining (Table 4). Different substantive issues, represented by the objects along the geotourist trail, are divided into six thematic groups: mineralogy, petrography, tectonics, palaeontology, mining and geomorphology (mostly karst, fluvial and denudation relief). In particular points of the trail, more than one thematic group is usually presented.

Table 4. Subject matter of the substantive issues represented by the objects on the geotourist

trail in the Upper Łagowica River valley (after Ludwikowska-Kędzia and Wiatrak, 2012; partially modified)

\begin{tabular}{|c|c|c|}
\hline Thematic group & Substantive issues & Trail object \\
\hline \multirow{2}{*}{ mineralogy } & symptom of hydrothermal processes - galena & 1,2 \\
\hline & secondary minerals in the Devonian carbonate rocks - calcite and dolomite & $9 \mathrm{a}-\mathrm{c}, 12$ \\
\hline petrography & mineral composition, structure and texture of limestones, dolomites, breccia & $4,9 \mathrm{a}-\mathrm{c}, 12$ \\
\hline \multirow{3}{*}{ tectonics } & geological profile of the Łagów syncline & $4,9 \mathrm{a}-\mathrm{c}$ \\
\hline & transverse faults in the southern wing of the Łagów syncline & $9 \mathrm{a}$ \\
\hline & strike-slip faults and slickenside & 12 \\
\hline \multirow{4}{*}{ palaeontology } & site with skeletal elements of the Late Devonian Placodermi & \multirow{2}{*}{4} \\
\hline & site with the remains of bony fishes from the Sarcopterygii group representing Tetrapodomorpha & \\
\hline & site of the Late Devonian cephalopod fauna - Goniatitida and Clymeniida & 6 \\
\hline & site of the Givetian Stromatoporoidea-Anthozoa fauna & $9 \mathrm{a}$ \\
\hline \multirow{2}{*}{ mining } & traces of historical ore mining - lead and pyrite ore & $1,2,12$ \\
\hline & transformation of the natural environment caused by modern mining of rock raw materials & 7,12 \\
\hline \multirow{3}{*}{ geomorphology } & $\begin{array}{l}\text { profile of the Quaternary deposits illustrating the coexistence of fluvial and slope processes, and aggradation of } \\
\text { deposits in the bottom of the valley }\end{array}$ & 13 \\
\hline & forms of surface, underground and reproduced karst & $3,5,7,8,9 \mathrm{a}, 10-12$ \\
\hline & lithological and tectonic conditions of the development of karst relief forms & $3,5,7-11,12$ \\
\hline
\end{tabular}

(b) range criterion - local route, but showing the unique in Poland features of geological structure and relief of the southern part of the Holy Cross Mountains.

(c) spatial criterion - land, surface-underground route, which runs both along the bottom of the valley, on its rocky slopes, and on flat denudation surfaces. Locally, at the points of cave occurrence and at the point with the Nawrocki shaft, it can run underground, but after adaptation of these objects.

(d) criterion of the number of tourists - route intended for individual tourists and small groups of tourists (maximum 10-15 people).

(e) criterion of the way of moving - pedestrian or bicycle route.

(f) length criterion - one-day or two-day route; length - $10 \mathrm{~km}$ (about $22 \mathrm{~km}$ as an alternative). 
In respect of educational content, the objects represent a large variety of issues from the categories of knowledge, skills and attitudes (Table 5), which can be presented during geoeducational classes for various groups of interested, i.e. school students, students, geotourists, tourist guides. The application nature of the conducted research in the Upper Łagowica River valley and its surroundings was confirmed by the activities of the Łagów commune authorities aimed at the promotion of geoeducation, organizing scientific conferences, popularizing meetings, field symposia or school workshops, and by the investment plans of the authorities of the city and commune of Łagów (establishing a lapidarium, making the Zbójecka Cave accessible to physically handicapped persons, and developing tourist infrastructure in the cave surroundings in the Dule gully).

Table 5. Category of educational and didactic issues implemented at the points of the geotourist trail in the Upper Lagowica River valley (after Ludwikowska-Kędzia and Wiatrak, 2012; partially modified)

\begin{tabular}{|c|c|}
\hline Issues by category: & Object number \\
\hline \multicolumn{2}{|l|}{ KNOWLEDGE } \\
\hline chemical composition, internal structure, morphology, mechanical and optical properties of the galena, calcite and dolomite crystals & $1,2,9 \mathrm{a}-\mathrm{c}, 12$ \\
\hline features of the environment of the Devonian organogenic limestone formation in the Holy Cross Mountains & $6,9 \mathrm{a}$ \\
\hline dolomitization process in the Devonian rocks of the Paleozoic massif of the Holy Cross Mountains according to different authors & $9 \mathrm{c}, 12$ \\
\hline features of the environment of the Devonian syngenetic dolomite formation & $9 \mathrm{c}$ \\
\hline Variscan tectonic deformations in the Holy Cross Mountains & $4,5,9 \mathrm{a}, 12$ \\
\hline causes of mass extinctions in Phanerozoic & 4 \\
\hline importance of fossil Stromatoporoidea-Anthozoa fauna in the reconstruction of the features of palaeoenvironments & $9 \mathrm{a}$ \\
\hline Late Devonian nekton fauna of intrashelf basin & 4,6 \\
\hline importance of conodont microfossils in the Devonian stratigraphy & 4,6 \\
\hline fossilization process of marine organisms and the types of fossils associated with it & $4,6,9 \mathrm{a}, \mathrm{c}$ \\
\hline historical and modern position of the Lagów region in the ore mining in the Świętokrzyski region & 1,2 \\
\hline conditions of formation and age of hydrothermal ores in the Paleozoic massif of the Holy Cross Mountains & 1,2 \\
\hline conditions of formation and age of ores formed by weathering in the Paleozoic massif of the Holy Cross Mountains & 2 \\
\hline ways of the former exploitation of ores in the Holy Cross Mountains & 1,2 \\
\hline modern mining of rock raw materials in the area of Łagów and its importance in the Świętokrzyskie Province & $12, \mathrm{~V} 1, \mathrm{~V} 2, \mathrm{~V} 4$ \\
\hline lithological and structural conditions of karst processes & $3,5,7-9 a, 10-12, \mathrm{~V} 1$ \\
\hline history of mining and geological researches and relationship of the former settlement with the natural environment & $\mathrm{i}, 7, \mathrm{~V} 3, \mathrm{C}$ \\
\hline record of aggradation in the bottom of the valley - the effect of cooperation of fluvial and slope processes & 13 \\
\hline \multicolumn{2}{|l|}{ SKILLS } \\
\hline describing macroscopic properties of galena, calcite, dolomite & $1,2,9 \mathrm{a}, \mathrm{c}, 12$ \\
\hline identification of mineral composition, structure and texture of carbonate rocks & $4,9 \mathrm{a}, \mathrm{c}, 12$ \\
\hline describing macroscopic properties of breccia & $9 \mathrm{a}, \mathrm{b}$ \\
\hline drawing of geological profile & 4,12 \\
\hline $\begin{array}{l}\text { determining the position of layers in space, based on the measurement of strike and dip angle of layers and determining the } \\
\text { direction of their dip }\end{array}$ & $4,6,9 \mathrm{a}, \mathrm{c}, 12$ \\
\hline $\begin{array}{l}\text { application of rules of determining the relative age of rocks and geological processes in accordance with the principles formulated } \\
\text { by Nicolaus Steno (1699) }\end{array}$ & $4,6,9 \mathrm{a}-\mathrm{c}, 12$ \\
\hline identification of fossils of benthos and nekton invertebrate fauna & $4,6,9 \mathrm{a}, \mathrm{c}$ \\
\hline identification of the types of fossils according to the way of formation & 4,6 \\
\hline identification of anthropogenic forms resulting from the extraction of ores & 1,2 \\
\hline identification of anthropogenic forms resulting from the extraction of rock raw materials & $12, \mathrm{~V} 1, \mathrm{~V} 2, \mathrm{~V} 4$ \\
\hline identification of surface and underground karst forms, explanation of the conditions of karst relief formation and karst process course & $3,5,7,8,9 \mathrm{a}, 10-12, \mathrm{~V} 1$ \\
\hline identification of the remains of former human settlements & $\mathrm{C}$ \\
\hline determining the type of interfingering boundary of slope and fluvial deposits & 13 \\
\hline reading depositional conditions, type and intensity of secondary processes that transform the Quaternary deposits & 13 \\
\hline \multicolumn{2}{|l|}{ ATTITUDES } \\
\hline respect for the principles of legal protection of geological heritage & $5-11$ \\
\hline respect for nature and its unchanging rights, and cultural heritage & $1-11,13, \mathrm{~V} 1-4, \mathrm{C}$ \\
\hline recognition of the achievements of knowledge in the field of earth sciences & $1-13$ \\
\hline cooperation in a group during practical classes & 4, 6, 9a,c, 12 \\
\hline regeneration of physical and mental forces through active rest & $1-13, \mathrm{~V} 1, \mathrm{~V} 3$ \\
\hline
\end{tabular}

\section{CONLUSIONS}

1. The small-scale geological and geomorphological objects as well as traces of former mining activities located in the Upper Lagowica River valley can be considered individually as geodiversity sites. However, their concentration in the valley, location in close proximity to each other as well as the accompanying viewpoints and culture points cause that these objects, when analysed together, strengthen their individual values. They are then attractive not only for an educator (e.g. teacher, tourist guide) and geotourist, but they are also promising for a potential investor.

2. The results of geotourist evaluation of the objects located in the Upper Lagowica River valley indicate their high and medium geotourist attractiveness, which justifies the marking out the proposed geotourist trail "Upper Łagowica River valley". This trail may become a showpiece promoting geotourism not only in the region, but on a supra-regional scale, it may increase the investment attractiveness of the area and at the same time arouse interest in the problem of changes and protection of the geodiversity of river valleys.

3. Geotourist evaluation of small objects in small river valleys, presented using the example of the Upper Lagowica River valley in the Holy Cross Mountains, together with the proposal to make out a geoturist trail in it, has application significance. It may help the local community to perceive the value of geodiversity and draw attention to the need for preservation and conservation of valuable geological and geomorphological objects in river valleys, may promote local and regional geotourism and increase the investment attractiveness of the area. 


\section{REFERENCES}

Alexandrowicz, Z., \& Alexandrowicz, S.W. (2002). Geoturystyka a promocja dziedzictwa geologicznego [Geotourism and the promotion of geological heritage]. In Partyka J. (ed.), Użytkowanie turystyczne parków narodowych. Ruch turystyczny - zagospodarowanie - konflikty - zagrożenia [Tourist use of national parks. Tourist traffic - management - conflicts - threats]. pp. 91-98, Instytut Ochrony Przyrody, Polska Akademia Nauk, Ojcowski Park Narodowy, Ojców.

Alexandrowicz, Z., Kućmierz, A., Urban, J., \& Otęska-Budzyn, J. (1992). Waloryzacja przyrody nieożywionej obszarów i obiektów chronionych w Polsce [Evaluation of inanimate nature protected areas and objects in Poland]. Państwowy Instytut Geologiczny, Warszawa.

Brilha, J. (2016). Inventory and quantitative assessment of geosites and geodiversity sites: a review. Geoheritage, 8, 119-134. https://doi.org/10.1007/s12371-014-0139-3

Bruschi, V.M., Cendrero, A., \& Cuesta Albertos, J.A. (2011). A Statistical approach to the validation and optimization of geoheritage assessment procedures. Geoheritage, 3, 131-149. https://doi.org/10.1007/s12371-011-0038-9

Chwastek, J., \& Janusz, W. (1991). Kamieniołom - „rana w krajobrazie” czy zabytek przyrody nieożyionej? [A quarry - a "wound in the landscape" or a monument of inanimate nature?]. Zeszyty Naukowe Akademii Górniczo-Hutniczej im. Stanisława Staszica w Krakowie, Górnictwo, 1448, 16, 2, 135-143 (in Polish).

Czermiński, J. (1960). Rozwój litologiczny serii węglanowej dewonu południowej części Gór Świętokrzyskich [The lithological development of Devonian carbonate series in the southern part of the Holy Cross Mountains]. Prace Instytutu Geologicznego, 30(2), 31-122 (in Polish).

Dmytrowski, P., \& Kicińska, A. (2011). Waloryzacja geoturystyczna obiektów przyrody nieożywionej i jej znaczenie w perspektywie rozwoju geoparków [Geotourism valuation of unbiotic objects and their signification in prospect of geopark development]. Problemy Ekologii Krajobrazu, XXIX, 11-20 (in Polish).

Dowling, R.K. (2011). Geotourism's Global Growth. Geoheritage, 3, 1-13. https://doi.org/10.1007/s12371-010-0024-7

Dryglas, D., \& Miśkiewicz K. (2014). Construction of the geotourism product structure on the example of Poland. In 14th GeoConferences on Ecology, Economics, Education and Legislation. International Multidisciplinary Scientific GeoConference. Conference Proceedings, 5(2), 155-162. SGEM, Sofia, Bulgaria.

Dzik, J. (2006). The Famennian "Golden Age" of conodonts and ammonoids in the Polish part of the Variscan sea. Acta Palaeontologica Polonica, 63, 1-360.

Fassoulas, C., Mouriki, D., Dimitriou-Nikolakis, P., \& Iliopoulos G. (2012). Quantitative assessment of geotopes as an effective tool for geoheritage management. Geoheritage, 4, 177-193. https://doi.org/10.1007/s12371-011-0046-9

Fijałkowska, E., \& Fijałkowski, J. (1971). Zaplecze surowcowe ośrodka garncarskiego w Lagowie [Sources of raw materials for the Łagów pottery centre][Raw materials for the pottery center in Lagów]. Rocznik Muzeum Świętokrzyskiego, 7, 185-224 (in Polish).

Fijałkowski, J. (1972). Zarys dziejów eksploatacji kruszców w rejonie Lagowa [An outline of the ore mining history near Łagów] [An outline of the history of exploitation of ore in the Łagów region]. In Kowalczewski, Z. (ed.), Dzieje i technika świętokrzyskiego górnictwa i hutnictwa kruszcowego [History and technology of the Świętokrzyskie mining and ore metallurgy]. pp. 121-125, Kieleckie Towarzystwo Naukowe, Wydawnictwa Geologiczne, Warszawa.

Grabowski, J., Narkiewicz, M., \& Sobień, K. (2006). Termiczne uwarunkowania zjawiska przemagnesowań dewońskich skat węglanowych w regionie kieleckim Gór Świętokrzyskich [Thermal controls on the remagnetization of Devonian carbonate rocks in the Kielce region (Holy Cross Mts)]. Przegląd Geologiczny, 54(10), 895-904 (in Polish).

Hadamik, C. (2004). Pradzieje i średniowiecze gminy Lagów w świetle dotychczasowych badan archeologicznych [Prehistory and the Middle Ages of the Łagów commune in the light of archaeological research to date]. In Mirowski, R. (ed.), Dzieje i zabytki matych ojczyzn [History and monuments of small homelands]. pp. 11-114, Gmina Lagów, Kielce.

Hełdak, D. (2016). The geotourist potential of the Bialka River valley (in the Podhale Basin) - a project of a geotourist trail. Geotourism, 44-45(1-2), 19-26. https://doi.org/10.7494/geotour.2016.44-45.1

Janiec, J., Romanek, A., \& Złonkiewicz, Z. (1992). Mapa Geologiczna Polski w skali 1:200000, arkusz Sandomierz. Mapa utworów powierzchniowych. Mapa podstawowa w skali 1:50 000, arkusz Łagów (853) [Geological map of Poland, scale 1:200,000, Sandomierz sheet. Map of surface sediments. Basic map in the scale of 1: 50,000 scale, Łagów sheet (853)]. Wydawnictwo Polskiej Agencji Ekologicznej S.A., Warszawa.

Jawecki, B., \& Tarka, R. (2017). GEO-PRODUKT od edukacji do innowacji [GEO-PRODUCT from geoeducation to innovation]. pp. 16-23, Wydawnictwo Ocean, Wrocław.

Kaczmarek, J., Stasiak, A., \& Włodarczyk, B. (2010). Produkt turystyczny. Pomysł, organizacja, zarzadzanie [Tourist product. Idea, organization, management], Polskie Wydawnictwo Ekonomiczne, Warszawa.

Kasza, A., \& Król, Z. (2019). Poszukiwania uranu w okolicach Daleszyc i Łagowa [Uranium exploration in the vicinity of Daleszyce and Łagów]. Studia Muzealno-Historyczne, 11, 139-150 (in Polish).

Kicińska-Świderska, A., \& Słomka, T. (2004). Projektowanie tras geoturystycznych [The construction of geoturist routs]. Folia Turistica, 15, 179-184 (in Polish).

Konon, A. (2008). Regionalizacja tektoniczna Polski - Góry Świętokrzyskie i regiony przyległe [Tectonic subdivision of Poland: Holy Cross Mountains and adjacent areas]. Przegląd Geologiczny, 56(10), 921-926 (in Polish).

Kot, R. (2006). Georóżnorodność - problem jej oceny i zastosowania w ochronie i ksztaltowaniu środowiska na przykładzie fordońskiego odcinka doliny dolnej Wisty i jej otoczenia_[Geodiversity - the issue of its evaluation and aplication in conservation and forming of the environment on the example of the Fordon's part of the lower Vistula valley and its surroundings], Towarzystwo Naukowe w Toruniu, Uniwersytet Mikołaja Kopernika, Torun.

Kotański, Z. (1959). Przewodnik geologiczny po Górach Świętokrzyskich [Geological guide-book to the Świętokrzyskie Mountains], 1-2, Wydawnictwa Geologiczne, Warszawa.

Kowalczewski, Z. (1971). Wybrane problemy dziejów kruszcowego górnictwa i hutnictwa na tle warunków geologicznych w Górach Świętokrzyskich [Some problems in history of ore mining and metallurgy in the Świętokrzyskie Mountains]. Przegląd Geologiczny, 19(10), 448-452 (in Polish).

Kowalczyk, M., \& Szrek, P. (2011). Wykorzystanie zasobów naturalnych a planowanie przestrzenne w gminie na przykładzie Łagowa (woj. świętokrzyskie) [The use of natural resources and spatial planning in the commune - Lagów case study (Świętokrzyskie Voivodeship)]. Czasopismo Techniczne (Technical Transactions), 17, 108, Architektura (Architecture), 6-A, 235-239 (in Polish).

Kowalski, B. (2002). Geneza układu sieci rzecznej w Górach Świętokrzyskich [Origin of the river network in the Holy Cross Mountains]. Prace Instytutu Geografii Akademii Świętokrzyskiej, 7, 315-351(in Polish).

Kubalíková, L. (2013). Geomorphosite assessment for geotourism purposes. Czech Journal of Tourism, 2(2), 80-104. https://doi.org/10.2478/cjot-2013-0005

Kubicki, R., \& Saletra, W. (2013). Hutnictwo i górnictwo w regionie świętokrzyskim - do Księstwa Warszawskiego [The steel and mining industry in the Świętokrzyskie region - to the duchy of Warsaw]. Studia i Materiały, Miscellanea Oeconomicae, 17(2), 29-40 (in Polish).

Ludwikowska-Kędzia, M. (2013). The assemblages of transparent heavy minerals in Quaternary sediments of the Kielce-Łagów Valley (Holy Cross Mountains, Poland). Geologos, 19, 95-129. https://doi.org/10.2478/logos-2013-0007

Ludwikowska-Kędzia, M. (2018). Litologia, geneza i stratygrafia osadów czwartorzędowych w poludniowej części Gór Świętokrzyskich [Lithology, origin and stratigraphy of Quaternary sediments in the southern part of the Holy Cross Mountains], Instytut Geografii Uniwersytetu Jana Kochanowskiego w Kielcach, Kielce.

Ludwikowska-Kędzia, M., \& Wiatrak, M. (2010). Obiekty geoturystyczne w dolinie Łagowicy na odcinku Łagów-Ruda [Geotourist objects in the valley Łagowicy Łagowica River valley on the Łagów-Ruda section]. Prace Wszechnicy Świętokrzyskiej, 133, 163-180 (in Polish).

Ludwikowska-Kędzia, M., \& Wiatrak, M. (2012). Atrakcyjność geoturystyczna doliny górnej Lagowicy. Propozycja trasy geoturystycznej [Geotourist attractiveness of the upper Lagowice valley. A proposal for a geotourist routel. Instytut Geografii Uniwersytetu Jana Kochanowskiego w Kielcach, Kielce.

Ludwikowska-Kędzia, M., Pasierb, B., Kasza, A., Wiatrak, M., \& Wałek G. (2019). Ptucki: uwarunkowania rozwoju i cechy rzeźby Doliny (Padołu) KieleckoLagowskiej - refrokras i kras kontaktowy Watu Małacentowskiego. Stanowisko 3.3. Płucki. [Ptucki: conditions for the development and relief of the Kielce-Lagów Valley (Depression) - refrokras and contact karst of Małacentowski Ridge. Stop 3.3. Płucki ]. In Urban, J., VII Warsztaty Geomorfologii Strukturalnej. Rzeźba strukturalna Gór Świętokrzyskich i Ponidzia - Stan badań i perspektywy badawcze [VII Structural Geomorphology Workshop. Structural morphology of the Holy Cross Mountains and Nida Basin - State of research and research perspectives]. pp. 124-130, Uniwersytet Jana Kochanowskiego w Kielcach, Kielce. 
Ludwikowska-Kędzia, M., Wiatrak, M., Olszak, I., \& Bluszcz, A. (2006). Litostratygrafia plejstoceńskiego tarasu wysokiego doliny Łagowicy w rejonie Masłowca (SE część Gór Świętokrzyskich) [Lithostratigraphy of the Pleistocene high meadow terrace of the Lagowica Valley near Masłowiec (SE part of the Holy Cross Mountains)]. Przegląd Geologiczny, 54(11), 953-962 (in Polish).

Mucivuna, V.C., Reynard, E., \& Garcia, M.d.G.M. (2019). Geomorphosites assessment methods: comparative analysis and typology. Geoheritage, 11, 17991815. https://doi.org/10.1007/s12371-019-00394-x

Najwer, A., \& Zwoliński, Z. (2014). Semantyka i metodyka oceny georóżnorodności - przegląd i propozycja badawcza [Semantics and geodiversity assessment methods - review and research proposal]. Landform Analysis, 26, 115-127 (in Polish). https://doi.org/10.13140/RG.2.1.3087.0883

Nita, J. (2012). Quarries in landscape and geotourism. Geographia Polonica, 85(4), 5-12.

Nita, J. \& Myga-Piątek, U. (2014). Geotourist potential of post-mining regions Poland. Bulletin of Geography, Physical Geography, 7, 139-156. https://doi. org/10.2478/bgeo-2014-0007

Orzechowski, S. (2007). Zaplecze osadnicze i podstawy surowcowe starożytnego hutnictwa świętokrzyskiego [Settlement facilities and raw material bases of ancient metallurgy in the Świętokrzyskie region], Kieleckie Towarzystwo Naukowe, Kielce.

Panizza, M. (2001). Geomorphosites: Concepts, methods and examples of geomorphological survey. Chinese Science Bulletin, 46, 4-6. https://doi.org/ $10.1007 / \mathrm{BF} 03187227$

Panizza, M. (2009). The Geomorphodiversity of the Dolomites (Italy). A Key of Geoheritage Assessment. Geoheritage, 1(1), 33-42. https://doi.org/ 10.1007/s 12371-009-0003-z

Prosser, C., Murphy, M., \& Larwood, J. (2006). Geological conservation - a guide to good practice, English Nature, Peterborough.

Reynard, E., \& Panizza, M., (2005). Geomorphosites: definition, assessment and mapping. An introduction. Gèomorphologie. Relief, processus, environment, 3, 177-180. https://doi.org/10.4000/geomorphologie.337

Reynard, E., Fontana, G., Kozlik, L., \& Scapozza, C. (2007). A method for assessing «scientific» and «additional values» of geomorphosites. Geographica Helvetica, 62(3), 148-158. https://doi.org/10.5194/gh-62-148-2007

Romanek, A., \& Złonkiewicz, Z. (1992). Mapa Geologiczna Polski w skali 1:200 000, arkusz Sandomierz. Mapa bez utworów czwartorzędowych. Mapa podstawowa w skali 1:50 000, arkusz Lagów (853) [Geological map of Poland, scale 1: 200,000, Sandomierz sheet. Map without Quaternary sediments. Basic map in the scale of 1: 50,000 scale, Lagów sheet (853)]. Wydawnictwo Polskiej Agencji Ekologicznej S.A., Warszawa.

Rubinowski, Z. (1971). Rudy metali nieżelaznych w Górach Świętokrzyskich i ich pozycja metalogeniczna [The non-ferrous metals ores of the Świętokrzyskie Mountains and their metallogenic position]. Biuletyn Instytutu Geologicznego, 247, 1-139 (in Polish).

Rubinowski, Z. (1974). Badania i udostepnianie jaskini Raj [Research and sharing of the Raj Cave], Kieleckie Towarzystwo Naukowe, Warszawa.

Strzyż, M., \& Wójtowicz, B. (2011). Koncepcja Geoparku Świętokrzyskiego - wybrane problemy [The concept of the Świętokrzyski Geopark - selected aspects]. Problemy Ekologii Krajobrazu , XXIX, 117-122 (in Polish).

Stupnicka, E., \& Stempień-Sałek, M. (2016). Geologia regionalna Polski [Regional geology of Poland], Wydawnictwa Uniwersytetu Warszawskiego, Warszawa.

Szrek, P., \& Salwa, S. (2020). High-energy events in the Frasnian-Famennian boundary interval of the Płucki section in the Holy Cross Mountains, Poland. Facies, 66(9), (2020). https://doi.org/10.1007/s10347-020-0593-0

Szuflicki, M., Malon, A., \& Tymiński, M. (2020). Bilans zasobów złóż kopalin w Polsce wg stanu na 31 XII 2019 r. [Balance of mineral resources in Poland as of December 31, 2019], Państwowy Instytut Geologiczny-Państwowy Instytut Badawczy, Warszawa.

Uberna, T. (1962a). Dolomity środkowo-dewońskie w Winnej koło Łagowa [Middle Devonian dolomites in Winna near Łagów]. Przegląd Geologiczny, 10, 515-519 (in Polish).

Uberna, T. (1962b). Zjawiska krasowe w dolomitach środkowodewońskich okolic Winnej koło Lagowa [Karst phenomena in the Middle Devonian dolomites in the vicinity of Winna near Łagów]. Przegląd Geologiczny, 12, 648-651 (in Polish).

Urban, J. (1996). Jaskinie regionu świętokrzyskiego [Caves of the Świętokrzyskie region]. Polskie Towarzystwo Przyjaciół Nauk o Ziemi, Warszawa.

Urban, J. (2014). Cechy rzeźby strukturalnej Gór Świętokrzyskich oraz południowo-wschodniej części Niecki Nidziańskiej [Features of structural morphology of the Holy Cross Mountains and the south-eastern part of the Nida Basin]. Przegląd Geologiczny, 62(1), 44-50 (in Polish).

Urban, J., \& Gągol, J. (2008). Geological heritage of the Świętokrzyskie (Holy Cross) Mountains (Central Poland). Przegląd Geologiczny, 56(8/1), 618-628.

Urban, J., \& Rzonca, B. (2009). Karst systems analyzed using borehole logs - Devonian carbonates of the Świętokrzyskie (Holy Cross) Mountains, central Poland. Geomorphology, 112, 27-47. https://doi.org/10.1016/j.geomorph.2009.04.024

Urban, J., Hercman, H., Ochman, K., \& Kasza A. (2019). Record of the Pleistocene at karst sites of the Świętokrzyskie (Holy Cross) Mountains region - a review. Studia Quaternaria, 36(2), 87-108.

Walczowski, A. (1962). Zjawiska krasowe $w$ utworach paleozoicznych $w$ okolicy Lagowa [The karst phenomena within the Palaezoic formations in the vicinities of Łagów]. Przegląd Geologiczny, 9, 457-460 (in Polish).

Walczowski, A. (1968). Objaśnienia do Szczegółowej Mapy Geologicznej Polski w skali 1:50 000, arkusz Łagów (853) [Explanations to the Detailed Geological Map of Poland, scale 1:50,000, Lagów sheet (853)], Wydawnictwa Geologiczne, Warszawa.

Wróblewski, T. (1977). Rzeźba Gór Świętokrzyskich [Geomorphology of the Holy Cross Mountains]. Rocznik Świętokrzyski, 5, 9-22 (in Polish).

Wróblewski, T. (2000). Ochrona georóżnorodności w regionie świętokrzyskim [Geodiversity conservation in the Góry Świętokrzyskie Region], Państwowy Instytut Geologiczny, Warszawa.

Znosko, J. (1962). W sprawie nowego nazewnictwa jednostek tektonicznych Gór Świętokrzyskich [On the new nomenclature of tectonical units of the Holy Cross Mts]. Przegląd Geologiczny, 9, 455-456 (in Polish).

Zwoliński, Z. (2004). Geodiversity. In Goudie, A.S., (ed.), Encyclopedia of Geomorphology, 1, pp. 417-418, Routledge, New York.

*** ANHC (2002). Australian Natural Heritage Charter for the Conservation of Places of Natural Heritage Significance, Australian Heritage Commission in association with Australian Committee for IUCN, Sydney.

Article history: $\quad$ Received: $10.09 .2020 \quad$ Revised: 07.10.2020 Accepted: 20.10.2020 Available online: 10.11 .2020

